\title{
Lawmaking by the Brazilian National Congress: Cooperation, leadership, and impasse between Brazil's Legislative and Executive branches*
}

\section{Fábio de Barros Correia Gomes}

Professor in political science (professional master's degree) at the Brazilian Chamber of Deputies Training Center (CEFOR) and legislative consultant for the Brazilian Chamber of Deputies.

E-mail: fabio.gomes@camara.leg.br

This article considers the working relationship between Brazil's Legislative and Executive branches. It identifies critical elements in Brazil's lawmaking system and strategic interactions between hierarchical legislative channels (constitutional, complementary, and ordinary) in the context of coalition presidentialism. This model was applied to bills submitted between 1999 and 2006, and generated data that runs counter to the widespread perception of a sharp divide between the agendas of the two branches and the hypothesis of absolute predominance by the Executive. However, the prevailing government coalition predominated in all lawmaking channels. The type of interaction (leadership, cooperation, or impasse) that developed between the branches seems to have been dependent on a particular bill's content.

Key words: Legislature; Executive; lawmaking; coalition; interactions

*This paper is a translation of the Portuguese original, entitled: "Cooperação, Liderança e Impasse entre o Legislativo e o Executivo na Produção Legislativa do Congresso Nacional do Brasil", published in: DADOS - Revista de Ciências Sociais, Rio de Janeiro, vol. 55, no 4, 2012, pp. 911 to 950.

Available in: http://dx.doi.org/10.1590/S0011-52582012000400003.

The original paper was received for publication in February 2012, resubmitted in August 2012 and approved in October 2012. 


\section{INTRODUCTION}

The study of interaction between the Brazilian Legislature and Executive as they produce federal laws has shown considerable development, thanks to the accumulation of information on these complex institutions. During the 1990s, discussions on this topic produced two diametrically opposed explanations. One of them pointed to decision paralysis and the other to an ability to govern, but under the predominance of the Executive.

The first indicates that the combination of presidentialism with a highly proportional (in the selection of deputies) and geographically unbalanced electoral system would disrupt the party system and generate an excess of veto points, making it difficult to define public policies of broad interest and at the same time facilitating interest group gains, which would lead to institutional chaos. According to this distributive approach, a president could not pursue her agenda in the face of a fragmented and particularistic Congress (Ames, 2001; Mainwaring, 1993).

And yet, Brazil has been internationally recognized for deploying consistent, stable, and broad-interest economic and social policies, a fact that flies in the face of such a prognosis ${ }^{1}$ and demands a greater understanding of the process of public policy development and a reassessment of assumptions about Brazil's institutional organization (Kingstone and Power, 2008). Some authors have resorted to the formulation of a paradox: How are inadequate institutions able to generate relevant and equitable policies? A revisionist explanation keeps intact the distributive model but replaces decision paralysis with the possibility of success through informal institutional relations, since fluidity in relations may facilitate the adoption of policies deemed necessary by elites (Armijo, Dembinska and Faucher, 2006).

The perception of decision paralysis was challenged, even in the 1990s, by empirical data about legislative production that recognized the critical role of the Executive, which had a success rate of approximately $90 \%$ and, moreover, authored $86 \%$ of the bills put before the government as a whole (Figueiredo and Limongi, 1999; 2004). Potential vetoes occasioned by the electoral system did not fully materialize in the legislative sphere, due to limitations imposed on realizing concrete benefits from exercizing the veto. This is because Congress had rules that centralized the decision-making process, favoring the role of party leaders in interactions with the President.

The argument of those who recognize that governability is grounded in

1. McGuire (2010) recognized the role of Brazilian democracy in the implementation of primary health care programs that contributed to the reduction of child mortality in the country. Melo (2008) highlighted the achievements of policies on education and health. Langoni (2010) noted the speed with which Brazilian institutions responded to the global economic and financial crisis that began in 2008, compared with European countries. 
instruments specified in the 1988 Constitution is central to the other side of the debate. Coalition presidentialism (where the ability to implement a government agenda depends on the strategic decisions of the President to build a coalition government) enhances governability, and the predominance of the Executive is a result of the President's greater access to legislative resources (Abranches, 1988; Pereira and Mueller, 2000; Amorim Neto, Cox and McCubbins, 2003; Santos, 2003). Consequently, the agenda and resulting legislation are strikingly national in scope, since the Executive tends to respond to national demands, and lawmakers tend to signal their preferences to the electorate by supporting-or not-the coalition government (Amorim Neto and Santos, 2003).

Initially, it was proposed that Executive predominance should be accompanied by a separation of powers: The Executive would deal with economic and administrative issues, the Legislature with social ones (Figueiredo and Limongi 1999; Santos, 2003; Amorim Neto and Santos, 2003). However, studies on the content of budgetary amendments submitted by Congress between 2001 and 2003 show that the changes effected by the Legislature in budgetary law complemented priorities set by the Executive, so that there developed a "merged substantive agenda" of the Executive and part of the Legislature, which not only anticipated, but incorporated, any reaction of the legislators (Figueiredo and Limongi 2009).

Although in recent years the evidence has favored the arguments of the second side of the debate, certain data have introduced new questions about the interaction between the branches in lawmaking. For example, after 1994 the Legislature increased its participation in authoring bills that become law to numbers exceeding those produced by the Executive (Figueiredo and Limongi 1999), and this trend has been sustained more recently (Carvalho and Gomes, 2008; Carneiro, 2009). ${ }^{2}$ The intense modification of bills and the activities of standing committees suggest that the interests of the Congress may be broader than was formerly recognized (Amaral, 2011; Carneiro, 2009; Cruz, 2009). ${ }^{3}$ Santos (1997) performed case studies on the production of high-salience legislation, such as setting taxes and the minimum wage, and observed conflict and

2. Carvalho and Gomes (2008) analyzed 15,246 ordinary bills (OB) introduced into the Chamber of Deputies between 1999 and 2006 and found that, among those converted into law up to March 2007, 53.5\% were authored by the Legislature and 38\%, by the Executive. Carneiro (2009) found that, between October 1988 and December 2007, the Legislature introduced 47.4\% of the ordinary laws from $\mathrm{OB}$ and the Executive, $42 \%$.

3. Amaral (2011) noted that the Chamber of Deputies changed $76 \%$ of the OB introduced between February 1995 and February 1996, with the changes made, mostly (67.9\%), through a substitutive amendment. Cruz (2009) found that 73.3\% of the Executive's OB, between 1999 and 2006, were subject to amendments and that $60.2 \%$ were actually modified by committees in the Chamber of Deputies. Of the Executive's OB, the author found that $49 \%$ of those drafted under the urgency regime were subject to approved substitutive amendment and $51.7 \%$ of those deliberated by the committees were altered. 
cooperation, opposing the cooperation guided by the Executive, deduced from aggregated analysis.

A better understanding of how the interaction between the branches takes place matters to those interested in what produces effective governing and how the political system remains representative. This article advances an analysis of the role of the branches in the national legislative process with emphasis on empirical data that qualify the Executive predominance in this process (the thesis with greater plausibility and better empirical evidence, thus a reasonable starting point) and on the search for related causal mechanisms.

\section{METHODOLOGY}

Initially, we identified the methodological issues that would have produced the different earlier diagnoses. One was an excessive emphasis on simplified models of legislative organization to represent complex institutions. The distributive, informational, and partisan perspectives (originally intended to clarify the operation of the strengthened committee system of the United States Congress) have generally been regarded as exclusive models, but since they address different dimensions of legislative organization (the types of policies produced, the organization of decision-making, and the resources available to decisionmakers), it is possible that they could be superseded over time as institutions develop.

In the case of the decision paralysis thesis, over-reliance on the distributive scenario with little consideration of how new constitutional rules might take effect, especially given the government's failure and crisis in the 1990s, may have prevented consideration of alternative hypotheses. The thesis of governability under Executive predominance (a reaction against the decision paralysis thesis) was based largely on a partisan perspective, and this explanation came to be highly influential.

Certain methodological issues may have distorted perceptions of the effective roles of the branches as well the agenda discussed in Congress. Of special note, the analysis breaks down due to the selection of: a) the actors (few studies address senators); b) the places where decisions are taken (the plenary of the lower Chamber of Deputies has been privileged); c) the types of legislative proposals and pathways used (proposed constitutional amendments and complementary bills are poorly studied); and especially d) the agenda effectively discussed in Congress (agenda items not made into law have been neglected).

Other issues include a lack of qualitative approaches that value the content and relevance of legislative proposals and the conflicts this may generate. Then there is the risk introduced by the indiscriminate aggregation of types of pro- 
posals, whereby analysis may be unduly influenced by attributes of the most frequent and miss variations of the less frequent, which may nonetheless be of greater relevance for public policy. Potential distortion can also be caused by considering authorship of legislation as the single determinant of leadership and by disregarding the constitutional rule that permits only the Executive to take initiative on administrative and budgetary matters.

Several authors have already argued the need to consider theoretical perspectives beyond the distributive one to understand the Brazilian case (Carvalho, 2003; Amorim Neto and Santos, 2003; Cintra, 2007; Almeida and Santos, 2009). Santos (1997) noted that methodological choices may interfere with the findings of studies on the relationship between the Executive and the Legislature, and on government capacity in Brazil, highlighting the need for a methodological "bridge" by which to analyze conflicting results.

A model for the Brazilian lawmaking system was subsequently elaborated to address the main problems that had been identified. This effort considered the vast domestic literature, but it was also influenced by the theoretical framework of historical institutionalism, as seen in the research of LeLoup and Shull (2002) and Jones (2005) that examines the relationship between the US President and the Congress. LeLoup and Shull (2002) reviewed the historical evolution of constitutional powers in the United States government, identifying the limits and potential of the actors in the production of laws. They used a typology based on the level of conflict generated by the content of policy and the types of leadership exercised by the President and the Congress, identifying their interactions as characterized by leadership of one of the actors, and their cooperation or impasse. Jones (2005) recognized the need to identify the advantages and strategic positions of the actors, as well as the resources available to them, to characterize the types of interaction between them. By analyzing the legislative history of significant cases he identified levels of competitiveness between the parties and stressed leadership exercised by the President and by Congress, as well as balanced ones.

From these authors' perspective, the problem was not identifying the dominant institution, but determining whether the system as a whole is able to solve problems set out in the political agenda. Although US institutions have different rules than the Brazilian government, they share similarities that can make such reflections useful for the Brazilian case -- mainly, the existence of branches that are institutionally separated, having democratically elected members who share power and must interact to produce public policies.

The resulting model seeks to integrate the systemic analysis of macroinstitutions (the branches of government) with the strategies of political microanalysis (individual actors) in an attempt to overcome the fragmentation produced by the isolated analysis of these elements. It eschews the adoption 
of institutional assumptions that emphasize only demands for particularistic policies or the mediation of the parties or the need for information resources. A concept map is presented in Figure 1 below.

Figure 1. Brazilian Lawmaking System after the Constitutional Assembly of 1987/1988

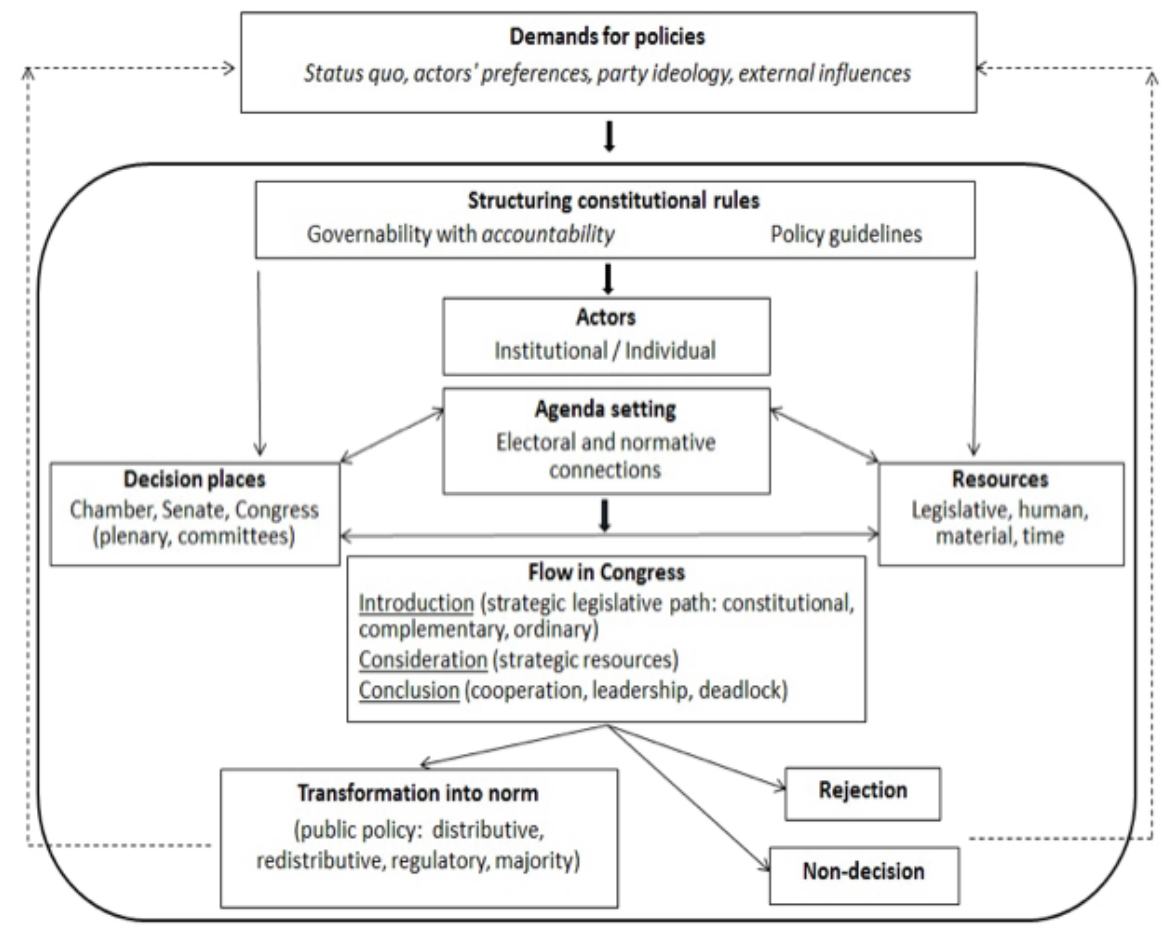

The model's main elements are: structural rules, actors, decision places, resources, and public policies (the result). The demand for policies that compose the legislative agenda are the inputs of the system. The structure is provided by the legal norm of the Federal Constitution, historically determined and continuously modified, due to critical changes in power. ${ }^{4}$ On one hand, this structure promotes governability with accountability to avoid the decision paralysis that occurred immediately prior to the establishment of the military government in 1964. Such governability would be ensured by the level of flexibility the Executive has to adopt legislation that would counter in a timely fashion economic and social problems (according to electoral inputs of national scope), counting on the cooperation of the Legislature through a negotiated agenda. That flexibility, however, would be limited by institutional arrangements that preserve

4. Pinto (2009) reviewed the texts of the Brazilian constitutions and found cyclic movements in which the lawmaking competencies of the branches varied according to the historical period, before achieving the current configuration. 
the power of Congress to express itself on all legislative proposals and hinder changes in constitutional norms. The pursuit of greater accountability from the President is exemplified by the requirement for legislative authorization of various types of specific budgetary transactions and by the provision of criminal liability in many political situations, but also in others more pragmatic in nature, such as running an investment program that is not included in the multi-year plan or otherwise sanctioned by law.

This structure favors the development of policies of social interest. The "constitutionalization" of that could have been treated in laws seeks to solidify social gains on a level where the Executive's field of action is more limited, due to stricter requirements for modification of the constitutional text. This results in path dependencies that the branches must observe and a normative connection between the constitution and future legislation. This structure is also supported by norms of the lower hierarchy, such as rules of the legislative chambers, which offer players different strategic channels by which to pursue their goals. ${ }^{5}$ Altogether, these rules create three legislative pathways-in hierarchical order, the constitutional, the complementary, and the ordinary.

The constitutional pathway allows only one type of legislative bill, the proposed constitutional amendment (PCA), which, to be approved, requires a super majority of three-fifths of congressional votes, in two votes of the plenary sessions of each chamber. Although both the Legislature and the Executive may initiate a PCA, it cannot be subject to an urgency petition or a presidential veto.

The complementary pathway also allows only one type of measure, the complementary bill (CB), whose subject is specifically mentioned in the Constitution. Its main role is to elaborate on constitutional issues regarding certain relevant topics. To be approved, the $\mathrm{CB}$ must pass the plenary of each chamber by an absolute majority. Approval in committee is not conclusive for these bills; that is, they must be considered by the plenary (at least in the Chamber of Deputies). The CB may be subject to an urgency petition or a presidential veto.

The ordinary pathway produces ordinary laws from three types of instruments: the ordinary bill (OB), the provisional measure (PM) and the National Congress bill (NCB). The latter two are used exclusively by the Executive. The OB has the largest number of potential authors, since it can be initiated by members of the Legislature, the Executive, the Judiciary, and even by citizens in specific circumstances. The $\mathrm{OB}$ is passed in each chamber by a simple majority. However, it can also be conclusively approved by committee; in other words, it can become law without the approval of the plenary. The NCB is related to the federal budget and is reviewed in joint sessions of Congress and enacted in only one round of voting, passing by a simple majority. The PM has immediate force of law and is valid up to 120 days, during which time the Congress can re-

5. These are influenced by: policy status quo, personal preferences, party ideology and demands of external actors such as interest groups, voters in general, and the media. 
ject it or convert it into ordinary law (any content modification will require the approval of a conversion bill). If Congress does not act within the prescribed period, the agenda of the plenary in the chamber where it is being processed is discontinued until a decision is reached. The urgency petition and the presidential veto are both allowed in this pathway.

Once a bill's authors select the most appropriate legislative channel, according to their policy objectives and political power, their proposals are considered in multiple decision-making venues (standing committees, ${ }^{6}$ temporary committees, the plenaries of each chamber, and in joint sessions of Congress). The specific location(s) are predetermined according to the legislation's content and relevance. There, the actors deliberate and contend, using the resources available to them. Some of these are legislative in nature, such as urgency petitions and the capacity of the session leadership to decide on which bills will be on its agenda. Other resources are non-legislative, such as time, manpower, materials, and information.

There is a regular sequence in the processing of bills: after approval by committee, a bill is voted on by the plenary and then considered by the other chamber. If it is amended it must be returned to the chamber of origin for evaluation of the amendments. Once approved by both chambers, the bill goes to the President, who can sanction or veto it (wholly or in part). A veto can be overridden by half of the members of each chamber. The most prominent outputs of this system are laws that impact public policy. ${ }^{7}$ Other possible outcomes are the rejection of or no decision on a policy.

This institutional framework allows various types of interaction between the branches: leadership by one of them, cooperation or impasse. These types are based on patterns of leadership-across the activities of initiating, modifying, or approving bills-and the level of conflict between them, expressed in efforts to modify or block bills. Cooperation is expected in routine administrative matters, regarding bills whose content generates low distributive conflict, and in cases of political bargaining. The ordinary pathway is the most likely to be involved in such cases. The use of resources is moderate and the process consensual, with an intermediate deliberation period (compared to other types).

A coalition across government is expected to lead in cases where legislative contents have moderate-to-high distributive impact or are of direct interest to the President (affecting governability, accountability, and the federal budget) and to the coalition. The Legislature is expected to lead in cases of low distribu-

6. There are 20 standing committees in the Chamber of Deputies and 11 in the Senate.

7. Such policies can be classified according to the typology developed by Lowi (1972) and Wilson (1973): distributive (costs are diffuse and benefits are concentrated), redistributive (both costs and benefits are concentrated), regulatory (costs are concentrated and benefits are diffuse), and majority (both costs and benefits are diffuse). 
tive conflict, broad societal support, symbolic measures, issues concerning the Legislature's own functions, or items that generate great social controversy and are too risky for the President to take sides on. Impasse would be expected in cases where the opposition tries to pass legislation that contradicts the majority coalition - on any pathway-or when a coalition tries to use the constitutional pathway without the support of a super majority, particularly on issues of high distributive conflict.

Once the institutional framework of the study was defined, its analyses were guided by descriptive issues. The key issue is verifying differences in the pattern of legislative production by analyzing the use of each legislative pathway during the twentieth century. This analysis considers whether the legislative agendas of the branches segmented according to the content of bills offered, and whether the Executive has dominated in the use of legislative resources and in its legislative output.

Here are the key analytical issues: What is the relationship between the requirements of the rules and the rates of success and dominance of the various actors? What is the relationship between legislative content that affects governability and observable interactions between the branches? To address most of these issues, the analysis considered 21,447 legislative proposals that could change a law or the Constitution and presented in the House of Representatives, the Federal Senate, and the Congress over a period of two terms (1999 to 2006). The databases were constructed from information collected from the websites of the House of Representatives, the Senate, and the Executive, using the LexML search engine. Additionally we used spreadsheets showing the status of proposals provided by the information technology bureaus of the first two institutions. A database from the Brazilian Center for Analysis and Planning (CEBRAP) was used to check the consistency of information on bills from the Executive and those converted into law. The database included information on authorship, content area-according to a typology used by Figueiredo and Limongi (1999), legislative resources used, status of the bill (verified in March 2009), and processing time.

Qualitative analysis was deepened by applying the first version of a typology for legislative proposals developed by the Group for Research and Extension on Health Policy of the Chamber of Deputies-GPE Saúde (Gomes, Carvalho and Reis, 2009) to a subset with 5.319 proposals related to public health. ${ }^{8}$

8. Health-related legislation was selected by virtue of the availability of a typology addressing proposals related to this policy area, ranging from issues restricted to it to issues that relate to other policies but reduce risks to health and so approach the status of rights. These allowed the author to observe and assess a wide variety of conflicts. 


\section{RESULTS}

The results are presented here according to the descriptive and analytical issues mentioned above.

\section{Trends in the Output of Legislative Pathways}

Until the 1960s, the constitutional pathway was little used (Graph 1), since many of the pressures caused by critical changes in the balance of power were accommodated by changing the Constitution itself. During the period of military rule, initiated in 1964, however, changes to the Constitution significantly increased. In the 38 years from 1926 to 1963 only 9 amendments were enacted, but in the following 22 years (1964 to 1985), 43 amendments were produced. In the current constitutional period, this trend has only grown, and in the past 19 years 66 amendments were produced, with notable acceleration from 1995 (Graph 1), soon after the constitutional revision of 1993.

In the complementary pathway, the total number of laws produced (169 since 1962, see Graph 2) is slightly higher than that of constitutional amendments (118 since 1926, see Graph 1), however, no more than 10 complementary laws have ever been produced in one year, so this pathway has a quantitative output well below that of the ordinary pathway. Before the military government of 1964, only 2 CB were approved each year, but between 1964 and 1985 there were 70, and since 1988, 88 (Graph 2).

Graph 1. Frequency of constitutional amendments promulgated from 1926 to 2010

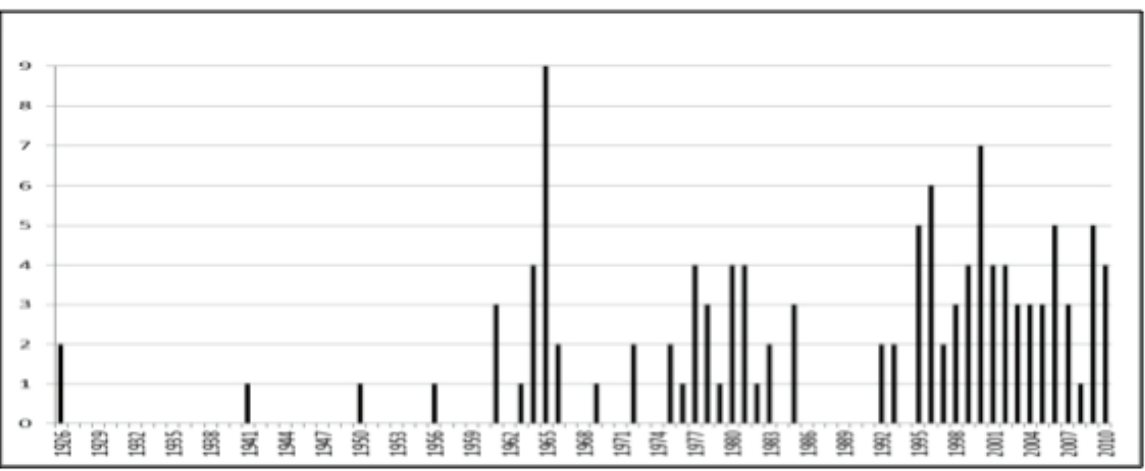

Source: Search engine of Lexml (http://www.lexml.gov.br).

The ordinary pathway has been the most used, especially during the democratic periods of the Republic. The production of ordinary laws was most intense between 1947 and 1963 (an annual average of 260),while between 1935 
Graph 2. Frequency of complementary laws produced from 1962 to November, 2010

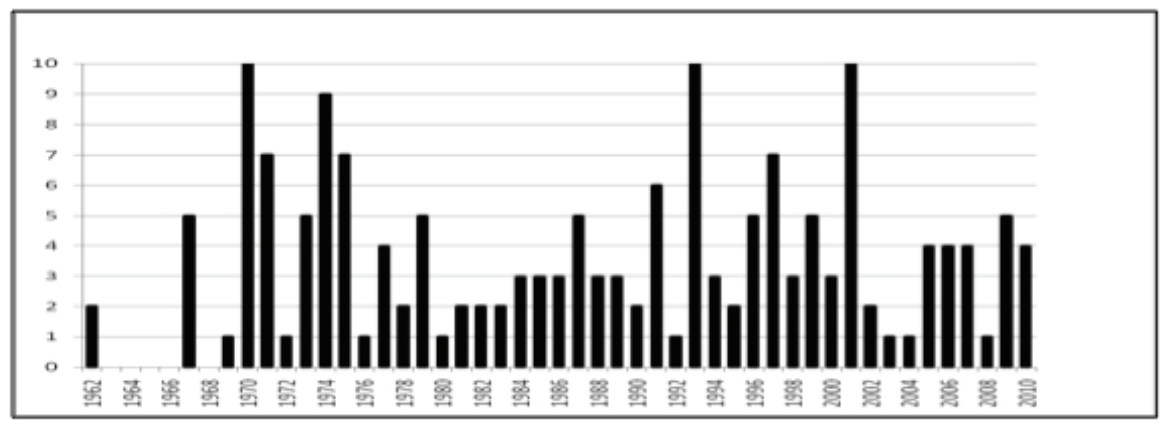

Source: Search engine of Lexml (http://www.lexml.gov.br).

Graph 3. Frequency of ordinary laws produced in Brazil from 1899 to 2010

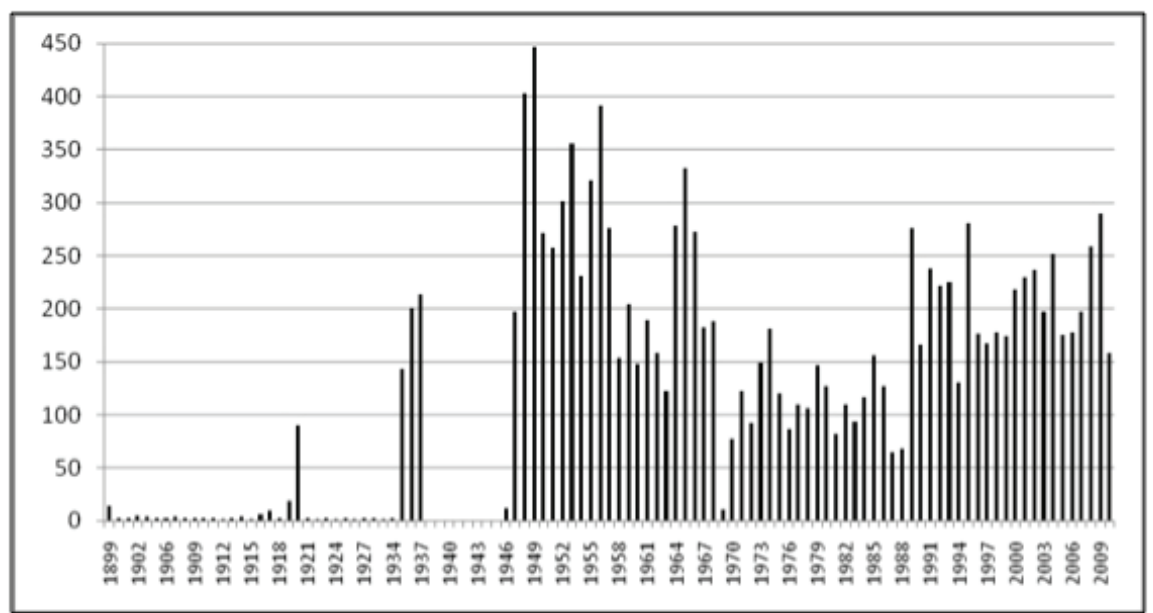

Source: Advanced search engine on legislation of the Chamber of Deputies` Internet website (http://www.camara.leg.br).

and 1937 the annual average was 186 laws; between 1964 and 1987, 139; and between 1988 and 2010, 204 (Graph 3).

However, it must be pointed out that the ordinary laws currently produced not only derive from OB, but also from NCB and PM. The use of NCB began with the military government of 1964 (Graph 4) in areas of high institutional relevance and the budget, particularly after 1972. (Currently NCB are only used in the budget area.) The average number of NCB presented annually was 55, between 1972 and 1987, and increased to 92 bills per year from 1988 to the present. This kind of proposal does not occur with elevated frequency in the early years of legislatures. 
Provisional measures (PM) are a democratic version of the old decreelaws that were used in the New State-annually averaging 988 between 1937 and 1946, and under the military government annually averaging 268 between 1966 and 1969, and 74 between 1970 and 1988. PM annually averaged 50 between 1989 and 2010, counting the original editions (Graph 5). Until 2001, PM not converted into law could be re-issued every month, which caused a geometric increase in reissued proposals, with an annual average of 600 PM reissues between 1993 and 2001. The year prior to the change in the handling of provisional measures saw higher numbers of them adopted; however, almost all were reissues. The number of new ones was much lower than in previous years, indicating that the situation was also harming the Executive. After 2001, changes in the processing of PM allowed an increase in the annual average of original bills, reaching 54.6, while in the previous period (between 1989 and 2001), the annual average had been 47.4 .

Graph 4. Frequency of National Congress Bills introduced from 1964 to 2010

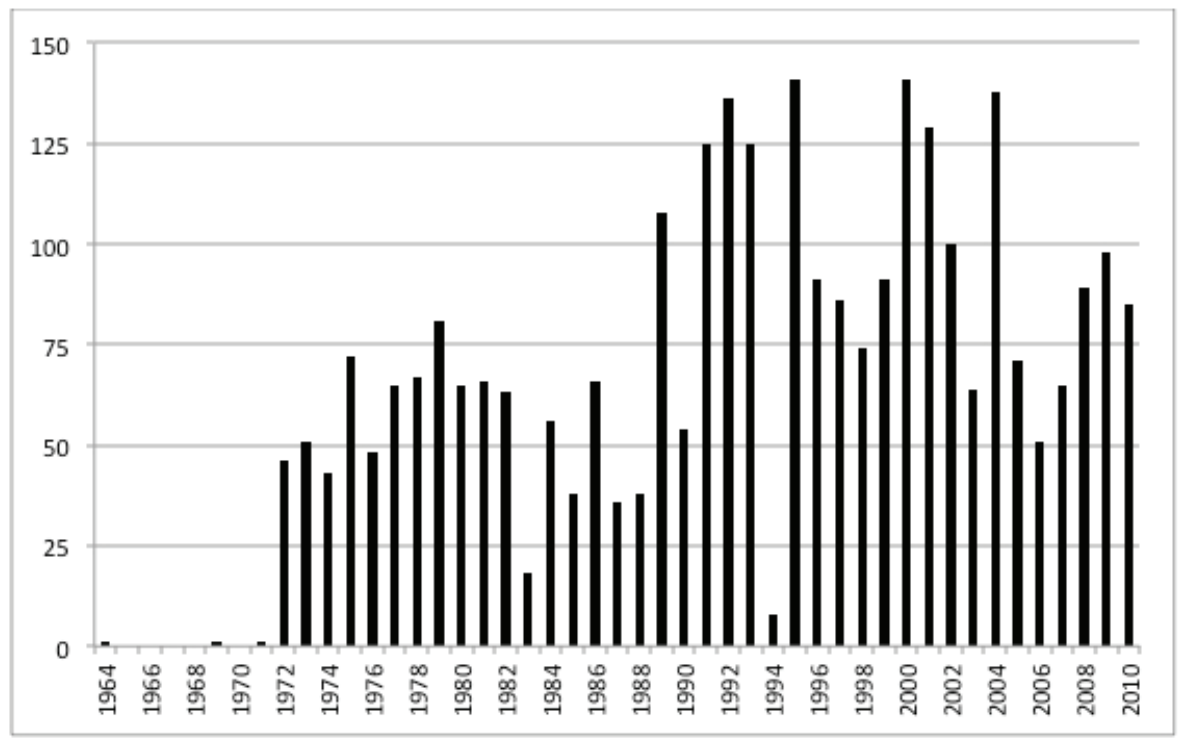

Source: Sicon's advanced search engine (Federal Senate's Internet website).

Information on "inputs" and "outputs" of the lawmaking system in two recent legislatures (between 1999 and 2006) confirm the particularities of each pathway. With regard to the introduction of proposals (Table 1), the ordinary was the most used pathway (87.9\%), and this reveals a particularly high use of the $\mathrm{OB}(81.8 \%)$. Use of the constitutional pathway, which has higher requirements for introduction and approval, was triggered more often (7.7\%) than the complementary (4.4\%). The Chamber of Deputies stood out as the key initiating chamber $(76.7 \%)$, but the Senate also contributed $17.3 \%$ of the total 
Graph 5. Frequency pf decrees-law and provisional measures issued from 1937 to 2010

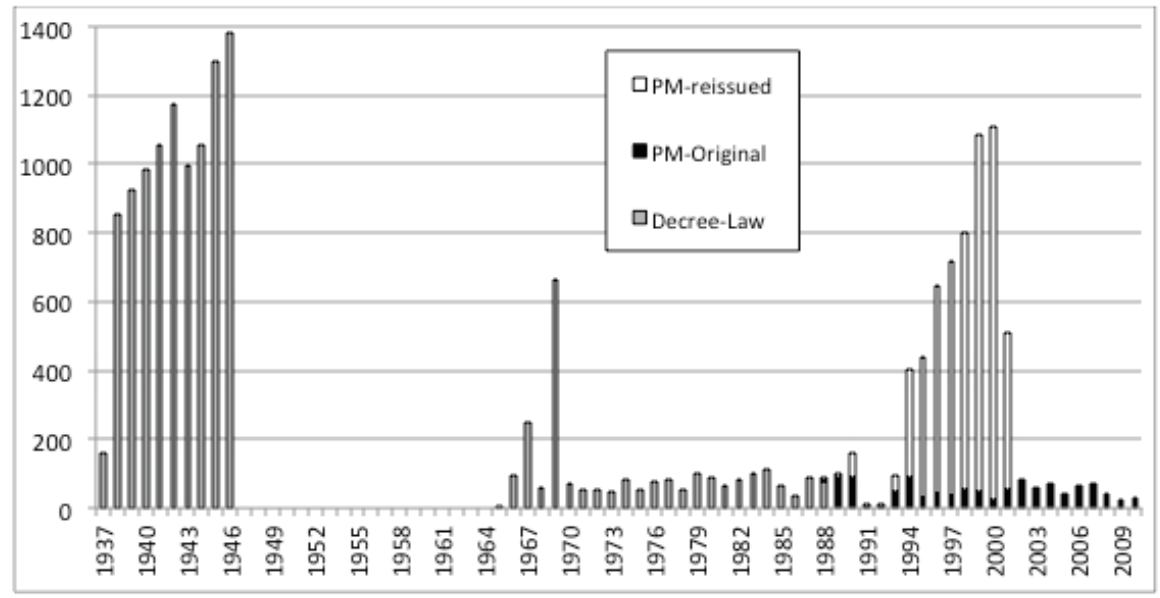

Source: Advanced search engine on legislation of the Chamber of Deputies ' Internet website, for the decrees-law, and Sicon's advanced search engine (Federal Senate's Internet website), for the provisional measures.

proposals, and more often used higher-level pathways than did the Chamber of Deputies: $13.6 \%$ vs. $6.9 \%$ at the constitutional level, and $6.3 \%$ vs. $4.4 \%$ at the complementary level.

The stereotype of a reviewer chamber, usually assigned to the Senate, was not confirmed in the constitutional pathway; instead, it sent 48 proposals to the Chamber of Deputies for revision in one period, while it sent only 20 to the Senate. In the complementary pathway, the numbers were similar, ${ }^{9}$ but the

Table 1. Legislative propositions introduced into the Chamber of Deputies, Senate and Congress between 1999 and 2006, by legislative pathway and place of introduction

\begin{tabular}{lcccrr}
\hline Legislative pathway / & \multicolumn{5}{c}{ Place of introduction } \\
\hline Type of proposition & Chamber & Senate & Congress & \multicolumn{1}{c}{ Total } & $\%$ \\
\hline Constitutional / PCA & 1,140 & 506 & - & 1,646 & 7.7 \\
Complementary / CB & 717 & 235 & - & 952 & 4.4 \\
Ordinary / OB & 14,584 & 2,970 & - & 17,554 & 81.8 \\
Ordinary / NCB & - & - & 783 & 783 & 3.7 \\
Ordinary / PM & - & - & 512 & 512 & 2.4 \\
Ordinary (subtotal) & 14,584 & 2,970 & 1,295 & 18,849 & 87.9 \\
Total & 16,441 & 3,711 & 1,295 & 21,447 & 100.0 \\
$\%$ & 76.7 & 17.3 & 6.0 & 100.0 & \\
\hline
\end{tabular}

Source: Study data set, based on the Legislative Information System (Sileg) of the Chamber of Deputies, the Prodasen of the Federal Senate and the Presidency's Internet website.

Legends: PCA - proposed constitutional amendment; CB - complementary bill, OB - ordinary bill; NCB - national Congress bill; PM - provisional measure.

9. The Chamber of Deputies reviewed 26 CB and the Senate, 27. 
Chamber of Deputies sent more ordinary bills for revision (903 as opposed to 602 from the Senate); even so, the Senate showed considerable activity, at $73.3 \%$ of the number of bills produced by the Chamber of Deputies in this pathway.

Regarding the ultimate success of bills sent along the three legislative pathways (Table 2$)$, total vetoes by the President were uncommon $(0.2 \%$ of bills introduced) and about a third of the bills were still being processed in March 2009. The exceptions to this were items introduced exclusively by the Executive, of which only $10.2 \%(\mathrm{PM})$ were still being processed, but had force of law, and none in the case of NCB. This indicates that these types of legislation were accorded rapid resolution. The success of the various proposals (Table 2) shows that $8.1 \%$ were passed, but the results in each pathway differed significantly.

The success rates of legislation show a gradation among the pathways. These were $9.0 \%$ for the ordinary, $2.6 \%$ for the complementary, and $1.3 \%$ for the constitutional. Of proposals that proceeded along the ordinary pathway, the two used exclusively by the Executive had very high success rates (91.7\% for NCB and $77.7 \%$ for $\mathrm{PM}$ ), ${ }^{10}$ while the OB, used by both branches, reached 3.3\% (which is still higher than the rate achieved via the complementary pathway).

In addition to differences in the relative efficiency of the pathways and the types of proposals, there was also variation in the number of laws each generated. Among all those analyzed, 21 amendments to the Constitution, 25 complementary laws, and 1,699 ordinary laws were sanctioned and promulgated, totaling 1,745. In the case of the ordinary pathway, the greater efficiency of PM and NCB was responsible for producing $65.7 \%$ of the ordinary laws, although they represented only $6.9 \%$ of the bills introduced in this pathway. But even with lower efficiency, the numerous OB resulted in more laws (583) than the PM (398). ${ }^{11}$

Finally, the specificity of the legislative pathways, the types of proposals that might travel along them, and associated quantitative results reinforce the relevance of their disaggregated analysis to evaluating the relationship between the branches, taking into account both the legislative chambers.

\section{THE BRANCHES` AGENDAS AND THE PERFORMANCE OF THEIR ACTORS}

Bills introduced between 1999 and 2006 were used to answer questions about agenda segmentation and the relative dominance of the branches. Those introduced by the Legislature were more numerous in all pathways (more than

10. In the case of PM, apart from the $77.7 \%$ converted into law, the $10.2 \%$ still being processed (allowed for those presented before the Constitutional Amendment \#32 of 2001) also have the force of law until there is new deliberation.

11. Even if the $52 \mathrm{PM}$ still in process with the force of law were added, the OB would have surpassed the number of PM. 
Table 2. Proportional distribution of processing status, for each strategic pathway and type of proposition, of bills introduced between 1999 and 2006, as verification conducted between February and March, 2009

\begin{tabular}{lcccccr}
\hline & \multicolumn{5}{c}{ Status of proposals (\%) } \\
\cline { 2 - 6 } & & \multicolumn{5}{c}{ Unconverted } \\
\cline { 2 - 6 } Legislative pathway / & $\begin{array}{c}\text { Converted } \\
\text { into a legal } \\
\text { norm }\end{array}$ & $\begin{array}{c}\text { Totally } \\
\text { vetoed }\end{array}$ & $\begin{array}{c}\text { Being pro- } \\
\text { cessed (*) }\end{array}$ & $\begin{array}{c}\text { Not being } \\
\text { Type of propsed }\end{array}$ & $\begin{array}{c}\text { Status not } \\
\text { specified } \\
(* * *)\end{array}$ & N \\
\hline Constitutional / PCA & 1.3 & - & 32.7 & 38.2 & 27.8 & 1,646 \\
Complementary / CB & 2.6 & 0.1 & 34.5 & 40.9 & 22.0 & 952 \\
Ordinary / OB & 3.3 & 0.2 & 35.4 & 47.9 & 13.1 & 17,554 \\
Ordinary / NCB & 91.7 & 0.0 & 0.0 & 8.3 & 0.0 & 783 \\
Ordinary / PM & 77.7 & 0.2 & 10.2 & 11.9 & 0.0 & 512 \\
Ordinary (subtotal) & 9.0 & 0.2 & 33.2 & 45.3 & 12.2 & 18,849 \\
Total & 8.1 & 0.2 & 33.2 & 44.6 & 13.9 & 21,447 \\
\hline
\end{tabular}

Source: Study data set, based on the Legislative Information System (Sileg) of the Chamber of Deputies, the Prodasen of the Federal Senate and the Presidency's Internet website.

Legends: PCA - proposed constitutional amendment; CB - complementary bill, OB - ordinary bill; NCB - national Congress bill; PM - provisional measure. $\mathrm{N}$ - total of propositions.

$\left.{ }^{*}\right)$ In the case of PM this column refers to "in process", but in any case producing the effect of law. In the case of other types, refers to the: appended, ready for the agenda, awaiting measure in the Chamber of Deputies or return from the Senate.

$(\star \star)$ In the case of PM this column refers to impaired, rejected, withdrawn or ineffective. In the case of other types, refers to the filed, returned to the author or transformed into new types of propositions.

$(* \star \star)$ Refers to proposals in the Senate, in which the available data didn't allow further status specification, but were not converted into law or forwarded to the Chamber of Deputies, up to March 2009.

95\% in each), ${ }^{12}$ even in the ordinary, where the Executive has three types of proposal it might deploy to achieve its aims. This contradicts the perception that Congressional interests are limited to particularistic issues. In absolute terms, the number of bills introduced by deputies was greater than that of all other actors. ${ }^{13}$ However, a comparison of the efforts in each chamber indicated the greater activity of senators in all pathways. Their activity was higher in the ordinary pathway ( 47.8 bills per senator to 29.7 per deputy), followed by the constitutional pathway ( 6.2 bills per senator to 2.2 per deputy) and the complementary ( 2.9 bills per senator to 1.3 per deputy).

Regarding the content of proposed legislation, Table 3 summarizes data on the policy areas that made up the agenda introduced between 1999 and 2006, and on those that succeeded in each pathway. A comparison of bills processed in the Senate with those processed in the Chamber of Deputies reveals the existence of thematic specializations in each legislative pathway that are similar in both chambers. For example, the political-institutional area is a significant

12. The Legislature authored $98.4 \%$ of the propositions in the constitutional pathway, $96.3 \%$ in the complementary, and $97.3 \%$ in the ordinary.

13. Deputies authored $94.5 \%$ of the proposals in the constitutional pathway, $92.9 \%$ in the complementary, and $90.8 \%$ in the ordinary, taking into account bills introduced into the Chamber of Deputies between 1999 and 2006. 
Table 3. Proportional distribution of policy areas of bills introduced between 1999 and 2006 and of those converted into legal norm, up to March 2009, from the perspective of processing in the Senate or in the Chamber of Deputies

\begin{tabular}{|c|c|c|c|c|c|c|c|c|c|}
\hline \multirow{3}{*}{ Policy area } & \multicolumn{3}{|c|}{ Constitutional } & \multicolumn{3}{|c|}{ Complementary } & \multicolumn{3}{|c|}{ Ordinary (OB) } \\
\hline & \multicolumn{2}{|c|}{ PRO $\left({ }^{\star}\right)$} & \multirow[t]{2}{*}{$\operatorname{NOR}(* \star)$} & \multicolumn{2}{|c|}{ PRO $\left({ }^{\star}\right)$} & \multirow[t]{2}{*}{ NOR $(\star \star)$} & \multicolumn{2}{|c|}{ PRO $\left({ }^{\star}\right)$} & \multirow[t]{2}{*}{ NOR $(* \star)$} \\
\hline & SF & $C D$ & & SF & $C D$ & & SF & $C D$ & \\
\hline Administrative & 27.4 & 22.0 & 9.5 & 24.0 & 21.0 & 40.0 & 9.8 & 6.8 & 18.5 \\
\hline Economic & 9.5 & 12.2 & 14.3 & 40.8 & 36.8 & 32.0 & 18.5 & 19.3 & 10.1 \\
\hline Honorific-symbolic & 0.2 & 0.1 & 0 & 0 & 0.1 & 0 & 5.8 & 4.1 & 22.8 \\
\hline Political-institutional & 34.2 & 26.5 & 4.8 & 13.7 & 8.5 & 4.0 & 4.6 & 2.8 & 1.5 \\
\hline Social & 28.7 & 39.2 & 71.4 & 21.4 & 33.6 & 24.0 & 61.2 & 66.9 & 47.0 \\
\hline $\mathrm{N}$ & 526 & 1188 & 21 & 262 & 743 & 25 & 3873 & 15246 & 583 \\
\hline
\end{tabular}

Source: Study data set.

Legends: SF- Senate; CD- Chamber of Deputies; OB- ordinary bill; PRO - processed; NOR - converted into norm; Ntotal of bills, corresponding to $100 \%$ in each column.

$\left.{ }^{*}\right)$ Refer to the perspective of processing for bills from all authors at the specified legislative chamber.

$(\star \star)$ According to the perspective of the Chamber of Deputies.

issue in the agenda introduced in the constitutional pathway, but of progressively lesser importance in the complementary and ordinary pathways. The economic area is key in the complementary pathway. Social issues are one of the two top areas on all pathways, but count for most of the agenda that proceeds along the ordinary pathway. The administrative area ranked third in frequency in almost every pathway, and the symbolic-honorific area was virtually nonexistent in the constitutional and complementary pathways, and occupied last place in the ordinary one.

Differentiation in the agendas of the two chambers is also noticeable: the political-institutional and administrative areas are more important in the Senate, while the social area is prevalent in the Chamber of Deputies across all pathways (Table 3). ${ }^{14}$ Graph 6 indicates that deputies and senators introduced more bills than did the Executive in all policy areas, on all pathways.

The social area was the most frequently addressed by the Executive in the constitutional pathway. ${ }^{15}$ The social was also privileged on the agenda that required constitutional approval, where both the Executive and Congress, especially senators, participated (Chart 6). Social issues were present in almost half of the ordinary laws produced from $\mathrm{OB}$, whether introduced by deputies or senators (47.2\% of 345), moreover accounting for 56\% of the 191 laws introduced by the Executive. Even among 512 provisional measures, the number concerned with social issues (41\%) exceeded those related to economic (37\%) and administrative issues (22\%).

It is striking that the representation of policy areas among the passed bills

14. Araújo (2009), who prioritized the Senate's processing of bills introduced between 1989 and 2004, found proportions of content and rankings similar to those found in this study.

15. Of the 19 PCA introduced by the Executive, 12 were in the social area. 
does not correspond to that among proposals introduced in chambers (Table 3 and Graph 6). For example, the social has gained prominence in the quantitative output of the constitutional pathway; the administrative area, in the complementary pathway; and the symbolic-honorific in the ordinary pathway. This suggests that the agenda "approved" by Congress does not proportionally reflect the one that was "introduced."

Although the high output of ordinary laws on honorific or symbolic topics (22.8\% of the total of 583 laws from $\mathrm{OB}$ ) reduces the relevance of what is produced in this pathway under the influence of the Legislature (author of $94.7 \%$ of such bills), this branch nonetheless also introduced more laws from OB than the Executive on economic issues (61\% of 59 laws), political-institutional issues ( $88.9 \%$ of 9 laws) and social issues (59.5\% of 274 laws). The Executive predominated only in the administrative area ( $48.1 \%$ of 108 laws), due to its exclusive competence in that area. ${ }^{16}$ Thus, the Legislature stepped beyond expressions of expected particularistic interests by also taking action on policies of broader interest.

This variety of interests and achievements in other areas suggests the existence of technical expertise in the Legislature. However, committees demonstrated low levels of activity as initiators of propositions in constitutional or complementary pathways (only 4 PCA and 10 CB from 1999 to 2006), but were slightly higher in the ordinary (198 OB, highlighting the Committee for Legislative Participation, which contributed $37.9 \%$ of the bills from committees). The ordinary pathway was the only one in which bills from committees were converted into law (at a rate of 2.3\%), exemplifying another device of the 1988 Constitution that is maturing. ${ }^{17}$

Regarding the performance of the actors, the findings confirm the recognized predominance of the Executive in the authorship of bills, but at a smaller percentage $(76.9 \%$ of the 1,699 pieces of legislation produced in the ordinary pathway and $76.1 \%$ of all 1,745 laws produced in all pathways) than the $86 \%$ found in the mid-1990s. The Executive' success and dominance were inversely proportional to the hierarchical level of the strategic pathway involved (Table 4). This gradation also occurred for all authors, but the Executive's level of success was noticeably higher (Table 4).

In the constitutional pathway, the Executive's performance was characterized by the introduction of few proposals ( $1.6 \%$ of $1,188 \mathrm{PCA})$, which prioritize issues that comprised the federal budget ( 6 of 7 constitutional amendments authored by the Executive were concerned with the budget). None of these suffered formal rejection. The Senate's achievement in this pathway (with higher success rates than the Chamber of Deputies and a higher absolute number of

16. The Judiciary also stood out in the administrative area, authoring $40.7 \%$ of the laws of that area.

17. [There was approval in the period after the one studied here, this way, such commission has potential for greater influence in the legislative process. 
Graph 6. Distributions of legislative bills with entry into the Chamber of Deputies between 1999 and 2006, according to authorship, policy area, status of conversion into norm (until March 2009) and legislative pathway

\section{Constitutional pathway}

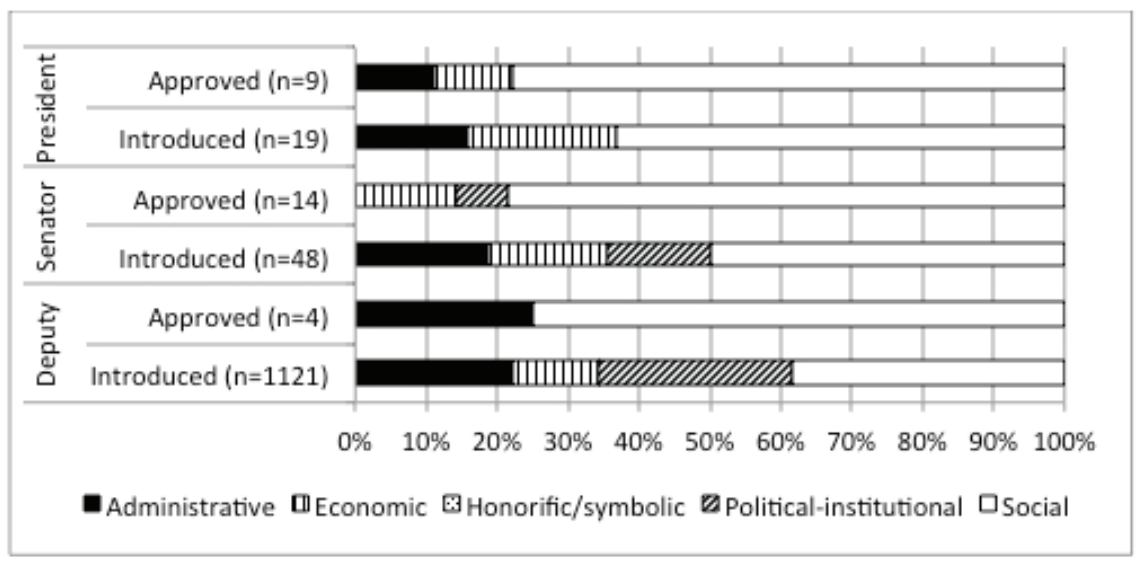

Complementary pathway

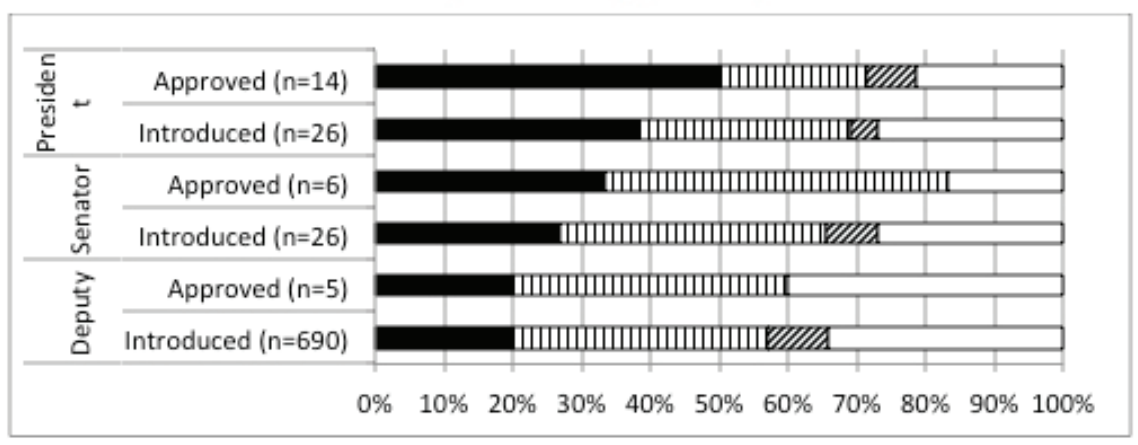

Ordinary pathway (OB)

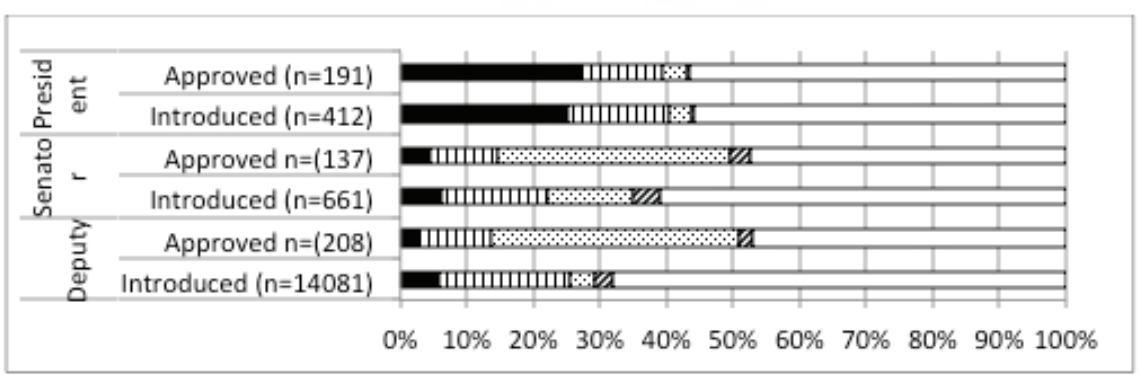

Source: Legislative Information System (Sileg) of the Chamber of Deputies. Study data set. 
Table 4. Distribution of rates of success and of dominance of propositions in all policy areas, from selected authors, by legislative pathway, which entered the Chamber of Deputies between 1999 and 2006, as verification conducted between February and March, 2009

\begin{tabular}{lcccc}
\hline \multirow{2}{*}{ Via } & \multicolumn{2}{c}{ Rate of success (\%) } & \multicolumn{2}{c}{ Rate of dominance (\%) } \\
\cline { 2 - 5 } & All authors & Executive & Executive & Coalition \\
\hline Constitutional & 1.3 & 36.8 & 33.3 & 90.5 \\
Complementary & 2.6 & 53.8 & 56.0 & 72.0 \\
Ordinary & 9.0 & 76.6 & 76.9 & 89.2 \\
OB $^{*}$ & 3.3 & 46.6 & 32.8 & 76.9 \\
PM & 77.7 & 77.7 & 100.0 & 100.0 \\
NCB & 91.7 & 91.7 & 100.0 & 100.0 \\
\hline
\end{tabular}

Source: Study data set.

*In the case of $\mathrm{OB}$, it was considered the entry in the Chamber of Deputies, during the study period.

successful constitutional amendments than even the Executive) departs from its role as only a reviewing chamber. ${ }^{18}$ It also suggests greater specialization and proactive interests (thanks to the nimble performance of its committees) in a pathway that, in principle, covers topics of high relevance, ${ }^{19}$ and strengthens the rationale for considering the authors of these measures in studies of the law and law-making.

In the complementary pathway, the role of senators was similar to that of the deputies (the former authored 5 laws and the latter, 6). The influence of the predominant coalition continued, but this time due to more direct action by the Executive (author of $56 \%$ of the complementary laws, $64.3 \%$ of them concerned with the federal budget). This was expected given the resources this actor enjoyed in this pathway (in particular the urgency petition and the presidential veto). However, the final complementary production of the coalition does not reach the same levels as the constitutional pathway, because the opposition achieved more successes than the members of Congress from the coalition did, including in bills with federal budget commitments. ${ }^{20}$ The authors in the Legislature produced more complementary laws with economic themes, ${ }^{21}$ and the Executive produced more administrative ones. ${ }^{22}$

18. Senators authored 506 PCA and eleven of those were converted into constitutional amendments (2.2\%), while Deputies had three successes (0.3\%) among 1,121 PCA and the Executive, seven successes (36.8\%) among nineteen PCA.

19. The higher level of importance of the agenda in this pathway was also suggested by the statistical meaninglessness of the honorific proposals introduced (one in the House and one in the Senate) and by the fact that neither was approved.

20. There were 7 laws from authors who belonged to the opposition when the CB were introduced ( 5 of them with budgetary commitments) and four laws from members of Congress who belonged to the coalition at the time of the bills' introduction.

21. The Legislature authored five complementary laws in the economic area and the Executive, three.

22. Seven of the ten complementary laws in the administrative area were authored by the Executive. 
In the ordinary pathway, deputies produced 1.5 more laws than senators, ${ }^{23}$ highlighting the social (47.1\% of 208$)$ and symbolic-honorific themes $(37.5 \%$ of 208), suggesting the increased responsiveness of these actors to the demands of society in addition to their particularistic interests. It should be stressed that, despite the greater involvement of senators with issues relevant to the constitutional pathway, they also addressed symbolic-honorific requests from their constituencies, passing them successfully at an even higher rate (39\% of 123 OB) than the deputies ( $14.8 \%$ of 526 OB).

The performance of the Executive in the ordinary pathway, on the kind of proposal that generates competition with Congress for claiming initiative (the $\mathrm{OB}$ ), had a success rate even lower than that obtained in the complementary pathway (Table 4). Still, Executive dominance in this pathway was assured by the high rates of passage for PM and NCB. The Executive's level of dominance in the legislative production of each pathway followed the same hierarchical tendency. Again, "dominance" was lower with respect to OB (Table 4).

These data contradict the thesis of the Executive's absolute predominance. They point to the better performance of the Legislature in higher-level pathways (as author of $66.7 \%$ of the constitutional amendments, highlighting production that originated in the Senate), and also in the case of OB (as the most prevalent author of legislation [59.2\%], with emphasis on the role of the Chamber of Deputies in the social area). However, before assuming the Legislature's predominance in these situations, we must consider data on the performance of the coalition, which indicate something different. The coalition's rate of dominance was high in all pathways $(89.2 \%$ in the ordinary, $72.0 \%$ in the complementary, and $90.5 \%$ in the constitutional). This breaks with the usual hierarchical pattern thanks to the high yield in the constitutional pathway (reaching 100\% among the constitutional amendments that relate to commitments of the federal budget). ${ }^{24}$ Thus, predominance in the legislative process occurs according to areas of relevance by activity of the coalition in all legislative pathways and through initiatives shared between the Executive and its Congressional base.

The commitment of the federal budget is a major factor that stimulates the efforts of the coalition to influence interaction between the branches. The budget issue was present in $47.6 \%$ of the laws produced in the constitutional pathway and $60 \%$ of those in the complementary. In the ordinary pathway, the laws from $\mathrm{OB}$ were not analyzed, but those from $\mathrm{NCB}$ and $\mathrm{PM}$ indicated that least $45.7 \%$ of the laws produced in this pathway concerned the federal budget. This situation was observed in the subset of proposals related to public health

23. Deputies authored 208 ordinary laws; Senators, 137; the Executive, 191; and 47 laws had other authors.

24. In the constitutional pathway, all 10 amendments having federal budget commitments were authored by the coalition ( 6 by the Executive and four by the Congress). 
that developed in the Chamber of Deputies. Among PCA, 37.2\% concerned the federal budget. In the group of public health-related actions and services, the level reached 59.6\%; in the group of benefits related to health, $36.5 \%$; in the group concerned with risk reduction, $14.8 \%$; and the group concerned with rights related to health, had no (immediate) budgetary implications. The last two issues were not involved in proposals from the Executive. The few times the Executive introduced a health-related bill in this pathway, it prioritized themes in the health-related actions and health services (5 of 6 PCA), yet in $83.3 \%$ of its PCA involved budgetary commitment. From the 9 successful PCA, $6(67 \%)$ had an impact on the federal budget.

Among health-related CB, 45.5\% involved the federal budget; of these "actions and services" reached 63.8\%, "benefits" reached 39.5\%, and "risk reduction," $18.2 \%$. The Executive introduced only three CB, all of them in the first thematic group, with commitments in the federal budget, in the period between 1999 and 2002.

In sum, findings indicate that the branches' agendas are not segmented; members of Congress have specific interests, but also broad ones; the level of the rules' requirements determines success rates inversely proportional to the complexity of the pathways, and the dominance of the actors varies in these pathways. The authorship of the Executive did not necessarily predominate, but the dominance of the coalition was undeniable.

\section{USE OF RESOURCES IN THE LEGISLATIVE PATHWAYS}

The performance of actors in the legislative process may be understood by observing their access to system resources, a factor that can influence the processing time of bills or modify their content.

Regarding the OB (the only type of legislation that may be approved conclusively by committee, that is, without consideration by the plenary), the plenary carried $39.1 \%$ of the conversions into law and the committees $58.3 \%$. The committees carried $70.7 \%$ of the laws authored by deputies and $81.8 \%$ of those authored by senators. The plenary carried $66.5 \%$ of the laws authored by the Executive and $51.1 \%$ of those having other authors (mainly the Judiciary). A conclusive evaluation by committee predominated in cases of symbolic-honorific measures $(91.0 \%)$ and showed some utility in the social (53.6\%), economic $(50.8 \%)$ and political-institutional areas (44.4\%). Plenary sessions produced the preponderance of laws in the administrative area (63.9\%).

The urgency petition in the complementary pathway was used in $3.4 \%$ of $743 \mathrm{CB}$, but with variations according to a bill's authorship: in $76.9 \%$ of $26 \mathrm{CB}$ from the Executive (in 11 cases per the requirement of Congress-the "legisla- 
tive" urgency-and in 9 cases, requested by the President himself, a so-called "constitutional" urgency), in $30.8 \%$ of $26 \mathrm{CB}$ authored by senators, and in only $4.6 \%$ of $690 \mathrm{CB}$ from deputies. An acceleration of the conversion of CB into complementary law was observed in the case of the constitutional urgency (with an average processing time of 265.7 days, far less than the usual 667.5 days average of this pathway); however, the urgency required by the Congress took an average of 919.1 days, greater than the average for this pathway. This, coupled with the fact that in general complementary laws were processed faster (an average of 347 days) than those with "legislative" urgency status, suggests that this procedure is used as a way to get issues on the agenda for a decision.

In the ordinary pathway, the use of the urgency petition was also associated with an unequal production of laws among actors. Of 345 ordinary laws from OB authored by the Legislature, $18.6 \%$ were benefited by this status, while for the 191 ordinary laws from the Executive the value was 64.9\% (and of these, $64.5 \%$ fell under "legislative" urgency). Furthermore, bills' conversion into law from urgency petitions was higher for the Executive (75.2\% of $165 \mathrm{OB})$, than for the Congress (44.9\% of 49 OB from senators and $5.7 \%$ of 732 OB from deputies).

Efforts to modify the contents of bills was studied on a smaller subset of those related to health, verifying a high level of involvement of the Legislature. In the constitutional pathway, $77.8 \%$ from 9 constitutional amendments related to health and $22.4 \%$ of 78 PCA were subject to a substitutive amendment (a type that usually produces changes of larger scope) during its passage in the Chamber of Deputies. In the complementary pathway, two laws were object of a substitutive amendment. In the ordinary pathway, amendments were presented in $74.2 \%$ of the $66 \mathrm{PM}$ converted into law (in 9 cases there were over 100 amendments, in the most extreme of these, 572 ). In $58 \%$ of the PM it was necessary to draw up a bill of conversion, indicating that the text was effectively modified by the Legislature. Regarding budget bills related to health, $37.8 \%$ of $82 \mathrm{NCB}$ received a substitutive amendment, but there was differentiation according to content. The substitutive amendment was used in $90.5 \%$ of $21 \mathrm{NCB}$ which established "guidelines" for the budget, but in $19.7 \%$ of 61 NCB on specific extraordinary credits.

Attempts to change a bill's content at the end of the legislative process are assessed by counting presidential vetoes. Considering the whole set (all themes), the high proportion of partial vetoes for 25 complementary laws (44\%) indicates that the Executive failed to sufficiently shape the deliberations on these matters, including the insertion of formal corrections. Even complementary laws authored by the Executive suffered partial vetoes (42.9\% of 14). None of these vetoes was taken up by Congress before 2004, contrary to the existing rules, and none of them was overridden.

The 38 total vetoes issued for bills in the ordinary pathway (all themes) also 
suggest that the coalition cannot always control the processing of bills. These cases involved no federal budget commitments, nor was there a higher concentration of $\mathrm{OB}$ from the opposition (47.4\%). Its association with conclusive approval by committees $(76.3 \%)$ suggests that the monitoring by the coalition did not work as efficiently in these instances and in this pathway (perhaps due to the low level of distributive conflict), or perhaps the coalition was simply not able to impose its interests universally. Anyway, these proposals (including those put forward by the coalition) did not succeed, for, as in the complementary pathway, vetoes generally were decided late in the process and none was overridden.

The time it takes for completion of the legislative process on average plays to advantage of the Executive in pathways where the urgency petition is available: the complementary and the ordinary pathways (Table 5). The expectation of a longer time on the constitutional pathway (due to the more stringent requirements for approval) was not confirmed. Rather, in this pathway, the Executive took an average of 315 days, almost three times faster than such bills handled by the Legislature and slower only than bills in the ordinary pathway. Of the ordinary Executive measures, PM averaged 91 days, and the NCB, 63 days. In this and in other pathways the average time-to-passage of bills initiated by the coalition were faster than those of the opposition (Table 5).

Bills that have failed end up differently, depending on the pathway and their authorship. The flow analysis of bills related to public health indicated that no-decision mechanisms, such as filing at the end of legislative session (due to absence of a committee report), were common in the constitutional and the complementary pathways- $73.8 \%$ and $76.6 \%$, respectively. In all pathways, the Executive's bills were rarely rejected or filed at the end, having been removed or blocked by a decision on another bill ( $60 \%$ and $35 \%$, respectively, for the $20 \mathrm{OB}$ from the Executive that had been filed). The $32 \mathrm{OB}$ filed by sena-

Table 5. Distribution of average processing time, according to the legislative pathways of propositions converted into legal norm, on all policy areas, from selected authors, which entered the Chamber of Deputies between 1999 and 2006, as verification conducted between February and March, 2009

\begin{tabular}{lccccc}
\hline & \multicolumn{5}{c}{ Average processing time (days) } \\
\cline { 2 - 6 } Pathway & Executive & Deputy & Senator & Coalition & Oposition \\
\hline Constitutional & 315 & 985 & 1.323 & 892 & 1.382 \\
Complementary & 520 & 1.093 & 656 & 553 & 961 \\
Ordinary & $*$ & $*$ & $*$ & $*$ & $*$ \\
OB & 451 & 1064 & 1129 & 788 & 1.134 \\
PM & 91 & - & - & - & - \\
NCB & 63 & - & - & - & - \\
\hline
\end{tabular}

Source: Study data set.

*Not calculated (see data for each proposition type of this pathway). 
tors suffered a different fate: $75 \%$ were formally rejected. The 25 OB authored by Chamber of Deputies committees were predominantly filed at the end of sessions (84\%). In a sample of 64 OB filed by deputies, it was found that among those processed under urgency rules, $87.5 \%$ were blocked, and among those processed otherwise, $52.9 \%$ were filed at the end of a legislative session.

In sum, the control of resources made available by institutional rules offered advantages to the Executive and to the coalition. Even the way proposals were filed demonstrates the differential access to resources by different actors. The urgency petition effectively accelerated the processing of the Executive's bills, but in the case of the Legislature, it behaved as a mechanism by which to get items on the agenda for a decision. The Executive focused on action by the plenary, and so the Legislature was left only the use of its committees, which have a slower flow-to-decision.

Even so, the Legislature has significant resources by which to modify the Executive's bills in all pathways. As a last resort, to control a bill's content, the Executive may exercise a full or partial veto, which at no occasion during the period under study was overridden by the Legislature. This involved collaboration of those responsible for the Congressional agenda, since deliberations on vetoes occur only years after they are issued, exemplifying the power of coordinators in setting the agenda for deliberation and even the output of the pathways.

\section{INTERACTIONS BETWEEN THE POWERS}

Cooperation between the branches was observed in the processing of the Executive's budget bills, using NCB. The content carried a low level for potential conflict, involving routine extraordinary credit openings (for example, in 75\% of the health-related NCB). Greater utilization of resources was observed for acceleration than for the obstruction of processing. The modification of NCB by Congress was considerable (but this did not necessarily indicate the existence of conflict, since it could reflect collaboration in the construction of a proposal). In conclusion, the average time of conversion into law was the lowest of the entire system, even lower than that of PM-just 63 days-and the success rate was the highest, with almost all being passed into law.

This cooperation would be institutionalized through rules that allow regular and quick solutions to budget issues using a smaller number of places where decisions can be made by a special and faster procedure. Quantitatively speaking, this kind of proposal by itself indicates cooperation as one of the more frequent types of interaction (due to the weight of NCB in the output of the ordinary pathway and of all pathways, corresponding to $41 \%$ ), but by no means 
does it suggest that the system is invariably cooperative, since that would disregard the issue of legislative relevance, which is one of the main contributors to the distinction of the pathways. The greatest problem this focus introduces is when the literature, considering the aggregated value of the laws produced, ends up inadvertently touting all the laws derived from NCB as evidence for the predominance of the Executive. This does not seem appropriate.

Another example of cooperation happens when the urgency regime is invoked, which depends on a majority vote, such as occurs when CB from the opposition are passed into law, including items that involve the federal budget. The leadership of the coalition evidently has significant weight in this type of interaction across all pathways. Items that involve distributive conflict and affect governability, as do the commitments of the federal budget, appear to attract the efforts of the Executive and its base, as observed in the two upper pathways. In the constitutional pathway, all approved constitutional amendments that involve the federal budget are authored by the coalition. Another clue is the gradation of the budgetary impact of health-related measures. Those measures with greater commitments are associated with areas of the greatest interest to the Executive. During processing, the coalition was observed to have an advantage in the use of resources such as the urgency regime, which effectively accelerated the progress of its proposals and took the lowest average time. Even in the constitutional pathway, where there is no such regime, progress was probably accelerated by the actions of coordinating legislators. In the end, leadership is expressed via high rates of success and the dominance of the coalition, and these are obtained by the Executive and its base in the Legislature, particularly in the Senate, sharing authorship.

The leadership of the Legislature cannot be explained only by significant findings of its predominance as the author of more law in the constitutional pathway or in the case of ordinary laws from OB. Again, qualitative considerations must be taken into account. The finding that the coalition obtained high rates of dominance in all pathways makes unlikely the predominance or autonomous leadership of the Legislative in these situations; this is consistent with the logic of coalition presidentialism. Not even expected leadership on bills of the political-institutional area or on those of the symbolic-honorific type (apparently less relevant and less interesting to the coalition and so more usually associated with approval by committee, giving deputies and senators their highest success rates) plays out in reality. Despite the higher number of these laws authored by the Legislature, the coalition prevailed even in these areas. There is nonetheless potential for the occurrence of this type of interaction to be captured in qualitative studies of specific policy areas.

Impasse situations evident in the total vetoes in the complementary and ordinary pathways (usually after lengthy deliberation) were absent in issues 
involving budget commitments, though these cases demand further investigation. A total veto in the complementary pathway, affecting a $\mathrm{CB}$ of the political- institutional area (about municipal elections) that was authored by the opposition suggests the importance of governability in the conflict between the players. Since none of the vetoes was overridden, only case studies can assess whether the impasses were overcome through the introduction of other proposals.

In general, the hypothesis that the potential budgetary impact of legislation shaped interaction between the Executive and the Legislature was strengthened. The greater that impact, the more the Executive and the coalition government would mobilize, with higher levels of conflict expressed in the use of resources at the various stages of the process.

\section{CONCLUSIONS}

The data suggest that the system works with regularities compatible with the institutional framework: in patterns of bills introduction, in the probabilities of dominance and success according to authorship, in the application of strategic resources, and in the final results of processing. The institutional arrangement has provided a regular and consistent lawmaking flow in pathways stratified by level of content relevance.

Legislative success rates, inverse to the hierarchical complexity of the pathways, indicate that there is greater ease of approval for policies in the lower pathways. The high success rates of the two types of proposals exclusively used by the Executive (both in the ordinary pathway), particularly in matters with budgetary content, suggest that the system is geared to provide the Executive with conditions necessary for governability in the context of coalition presidentialism. It offers normative directives aiming at a balanced budget and social equity and the strategic means for solving national problems; mainly in the ordinary pathway. In this context, the Legislature retains enough power to offer the final word on the approval of the matters in any pathway, particularly in the constitutional. This is especially relevant considering that most public policies are "constitutionalized."

The system proved to be dynamic and was identified with the progressive maturation of institutional initiatives aimed at strengthening the standing committees of the chambers and, thus, their ability to guide public policy. However, the influence of a certain level of informality in the implementation of some important rules (such as those related to the processing of PM and the consideration of presidential vetoes) cannot be ruled out. These have influence on matters of high relevance.

Still, formal rules matter in Brazil, so it is not plausible to explain the "Bra- 
zilian paradox" based only on informalities, or to argue that this would be a useful feature for emerging democracies. The observed patterns reaffirm the role of rules in policy making, suggesting that the system is not chaotic and that the country's political institutions have been crucial in overcoming impasses in the production of public policy, through negotiation between the branches in the period since the 1988 Constitution.

The analysis of the legislative agenda, which incorporated all bills introduced in a given period and in all places where decisions were taken in Congress, allows the identification of thematic specializations in legislative pathways, with some variation in the intensity with which issues were addressed in each chamber. This was so even though the contents were similar in each pathway.

Relevant to reflections on representation, the findings contradict the perception that members of Congress pursued legislative interests that predominantly sought to satisfy interest groups, as opposed to the broader interests of society. This perception is shaken by the finding that the Legislature was the most active proponent of bills in all pathways, engaging more than $90 \%$ of the legislative proposals, highlighting the activity of the Senate (especially in the pathways of higher rank) relative to the number of members, and the Chamber of Deputies, in terms of total numbers. These findings clarify those of past analyses, which prioritized only proposals that became law. It is noteworthy that the extent of the activity of the Brazilian Legislature in proposing bills is similar to that experienced elsewhere in Latin America, for example, the Argentinean Congress introduced ten times more bills than did the President (Alemán and Calvo, 2008).

The data also oppose an agenda demarcation between the branches, consistent with the conclusion of Figueiredo and Limongi (2009) on the "fusion" of the substantive agenda of both, the Executive and some part of the Legislature. The Executive submitted proposals in the social area in all pathways and, even when using PM, acted more often in this area. Among Congress, the social area was the most frequent subject of bills in the ordinary pathway. ${ }^{25}$ There was also an increased production of social policy law in this pathway by Congress, but other policy areas stood out in other pathways, such as CB dealing with economic issues.

Legislators' range of interests and the results obtained in the economic area suggest the existence of informational capacities in the Legislature. However, the number bills authored by standing committees was low, suggesting the relative inability of committees to guide an autonomous legislative agenda.

Although the Legislature has excelled in producing laws of constitutional content, this study also draws attention its high proportion of measures in the symbolic-honorific area, indicating that members of Congress have both dis-

25. As also noted by Amorim and Santos (2003) in the deputies-authored OB introduced in 1995. 
tributive interests, due to their electoral connections, and broad ones, for example through their adherence to coalition programs.

Another finding of interest with respect to the agenda was that policy areas introduced in the pathways of both chambers did not have the same weight in the approved agenda. This suggests that the centralizing mechanisms of decision-making, as identified in the literature, are facilitating the deliberative process, which favors governability. But Congress may not be able to influence public policy as the people they represent desire, which has implications for the quality of democracy.

In interactions between the branches, variations related to differentiated access to legislative resources by actors were observed. At the aggregate level, the data do not generally differ from the original findings of quantitative predominance of the Executive in the total legislative output (Figueiredo and Limongi 1999). The statistic indicating that $86 \%$ of production until the mid1990s was predominantly authored by the Executive was confirmed in Carneiro (2009), which considered the period 1988 to 2007, finding a value of $79.7 \%$, very close to the value found in this study $-76.9 \%$ for the case of the ordinary pathway. Thereby, it can be reasserted that the Legislature does not represent an obstacle to the Executive's performance.

However, the fact that the Executive prevailed in the production of law through its exclusive types of lower-level proposal has led to an overestimation of the dominance of this branch and a disregard of the importance of coalition presidentialism. Moreover, the sometimes dramatic changes made by the Congress to the Executive's bills also indicates that the predominance of the Executive is not the only viable explanation of policymaking in Brazil, especially when one considers the relevance of the proposals (stratified in the three pathways).

Executive success and dominance rates were inversely proportional to the hierarchical level of the pathways, contradicting the thesis that it would be quantitatively dominant in the higher pathway, where the Legislature in fact authored $66.7 \%$ of the constitutional amendments, most notably production that originated in the Senate. This points to specialization in the work of Senate committees. The inversion was also true for laws passed from $\mathrm{OB}$, of which the Legislature again authored 59.2\%, with the Chamber of Deputies contributing the most in the social area. Still, dominance of the coalition on all pathways was clearly demonstrated, reaching $89.2 \%$ in the ordinary pathway, $72 \%$ in the complementary and $90.5 \%$ in the constitutional. These findings, of strong coalition dominance in the amount and speed of laws produced in all pathways, make sense by the logic that the system is geared to promote governability.

Besides clarifying the leadership of the coalition, the study's systemic observation of the functioning of the legislative pathways also permitted the collection of evidence that other types of interaction around legislation took place, 
such as cooperation (particularly in the case of common budget laws) and impasse. These findings still require further qualitative deepening, especially regarding the occurrence in the current context of the Legislature's leadership.

Since the level of conflict generated by a proposal is an important motivator of greater involvement by the Executive and its support base, it is plausible that federal budgetary commitments draw special attention. The Executive, already heavily restricted by constitutional provisions in its ability to direct new spending, is likely to withstand a greater load of obligations. Brady and Volden (2006) highlighted the importance of distinguishing legislation with a budgetary impact, which proves well suited to the Brazilian case. However, non-budgetary content regarding accountability, governability, or more broadly "governance capacity," in the terminology of Santos (1997), also can lead to conflict. In short, distributive conflict and governability issues seem to be at the base of the various types of interaction between the Executive and Legislative branches in Brazilian coalition presidentialism.

The use of a systemic and strategic approach here, considering Brazil's historical context, attenuates fragmentation in analysis of the agenda and facilitated analysis integration of macro (between institutions) and micro (between actors) relationships, which considered separately would have produced diverse results. When further qualified by the institutional framework presented, based heavily on the constitutional standard and on consideration of the conflict generated by policy content between systemic and strategic interests, those micro and macro interactions were shown to be part of the same dynamics.

\section{REFERENCES}

ABRANCHES, Sérgio. (1988), "Presidencialismo de Coalizão: O Dilema Institucional Brasileiro." Dados, vol. 31, no. 1, pp. 5-34.

ALEMÁN, Eduardo and CALVO, Ernesto. (2008), "Analyzing Legislative Success in Latin America: The Case of Argentina," in G. O'Donnell et al (eds.), New Voices in the Study of Democracy in Latin America. Washington, D.C., Woodrow Wilson International Center for Scholars.

ALMEIDA, Acir S. and SANTOS, Fabiano. (2009), "Urgency Petitions and the Informational Problem in the Brazilian Chamber of Deputies". Journal of Politics in Latin America, vol. 3, pp. 81-110.

AMARAL, Ana Regina V. P. (2011), "O Parlamento Brasileiro: Processo, Produção e Organização Legislativa: O Papel das Comissões em Perspectiva Comparada", in J. Nicolau e R. Braga (orgs.), Para Além das Urnas: Reflexões sobre a Câmara dos Deputados. Brasília, Câmara dos Deputados, pp. 149-176.

AMES, Barry. (2001), The Deadlock of Democracy in Brazil. Ann Arbor, The University of Michigan Press.

AMORIM NETO, Octavio, COX, Gary and MCCUBBINS, Mathew. (2003), "Agenda 
Power in Brazil's Câmara dos Deputados, 1989-98." World Politics, vol. 55,no 4, pp. 550-578.

AMORIM NETO, Octavio and SANTOS, Fabiano. (2003), "O Segredo Ineficiente Revisto: O que Propõem e o que Aprovam os Deputados Brasileiros”. Dados, vol. 46, no 4, pp. 661-697.

ARAÚJO, Paulo M. (2009), O Bicameralismo no Brasil: As Bases Institucionais e Políticas do Desempenho Legislativo do Senado Federal (1989-2004). PhD thesis. Belo Horizonte, Universidade Federal de Minas Gerais.

ARMIJO, Leslie E.; FAUCHER, Philippe and DEMBINSKA, Magdalena D. (2006), "Compared to What? Assessing Brazil's Political Institutions". Comparative Political Studies, no 39, pp. 759-786.

BRADY, David W. and VOLDEN, Craig. (2006), Revolving Gridlock. Politics and Policy from Jimmy Carter to George W. Bush (2a ed.). Boulder, Westview Press.

CARNEIRO, André Corrêa de S. (2009), Legislação Simbólica e Poder de Apreciação Conclusiva no Congresso Nacional. Master dissertation, Rio de Janeiro, Instituto Universitário de Pesquisas do Rio de Janeiro / Centro de Formação da Câmara dos Deputados.

CARVALHO, Eduardo L. and GOMES, Fábio B. C. (2008), "Características da Tramitação de Projetos de Lei Ordinária Apresentados na Câmara dos Deputados entre 1999 e 2006", in D. Messenberg et alii (orgs.), Estudos Legislativos. Pensamento e Ação Política. Brasília, Câmara dos Deputados, pp. 285-289.

CINTRA, Antonio O. (2007), "O Congresso Nacional: É Preciso Mudanças? Exame de Algumas Propostas”, in J. Nicolau and T. Power (orgs.), Instituições Representativas no Brasil: Balanço e Reforma. Belo Horizonte/Rio de Janeiro,UFMG Editora/ IUPERJ, pp. 11-35.

CRUZ, Márcia R. (2009), Legislativo Transformador? As Modificações do Legislativo nos Projetos de Lei do Executivo. Master dissertation, Rio de Janeiro, Instituto Universitário de Pesquisas do Rio de Janeiro/Centro de Formação da Câmara dos Deputados. Available at http://www2.camara.gov.br/responsabilidade-social/ edulegislativa/educacao-legislativa- 1/posgraduacao/arquivos/publicacoes/tesesminter/DissertacaoMarciaRodriguesMinterluperj.pdf. Acessed in 1/4/2011.

FIGUEIREDO, Argelina C. e LIMONGI, Fernando (1999), Congresso Nacional: Organização, Processo Legislativo e Produção Legal: Guia do Lobby I. Brasília, Inesc.

. (2004), "Modelos de Legislativo: O Legislativo Brasileiro em Perspectiva Comparada". Plenarium, ano I, no 41, pp. 41-56.

. (2009), "Poder de Agenda e Políticas Substantivas", in M. Inácio and L. Rennó (orgs.), Legislativo Brasileiro em Perspectiva Comparada. Belo Horizonte, UFMG Editora, pp. 77-104.

GOMES, Fábio B. C. (2011), Interações entre o Legislativo e o Executivo Federal do Brasil na Definição de Políticas de Interesse Amplo: Uma Abordagem Sistêmica, com Aplicação na Saúde. PhD thesis, Rio de Janeiro, Universidade do Estado do Rio de Janeiro. Available at http://bd.camara.gov.br/bd/bitstream/handle/bdcamara/6165/interacao legislativo gomes.pdf?seque nce $=1$. Acessed in 7/25/2011. , CARVALHO, Eduardo L. e REIS, Rodolfo. (2009), "Projetos de Lei Ordinária Apresentados na Câmara dos Deputados entre 1999 e 2006: Tramitação Geral e dos Relacionados à Saúde”. E-Legis - Revista Eletrônica do Programa de PósGraduação da Câmara dos Deputados, no 2. Available at http://inseer.ibict.br/elegis/index.php/e-legis/article/view/10/8. Acessed in 1/4/2011. 
JONES, Charles. (2005), The Presidency in a Separated System. Washington, D.C., Brookings Institution Press.

KINGSTONE, Peter R. and POWER, Timothy J. (2008), Democratic Brazil Revisited. Pittsburgh, University of Pittsburgh Press.

LANGONI, Carlos. (2010), Conta Corrente Analisa Crise Econômica da Grécia. Interview in the program Conta Corrente, GloboNews, may.

LELOUP, Lance T. and SHULL, Steven A. (2002), The President and Congress: Collaboration and Combat in National Policymaking. NewYork, Longman.

LOWI, Theodore J. (1972), "Four Systems of Policy, Politics, and Choice". Public Administration Review, vol. 32, no 4, pp. 298-310.

MCGUIRE, James W. (2010), Wealth, Health, and Democracy in East Asia and Latin America. New York, Cambridge University Press.

MELO, Marcus A. (2008), "Unexpected Successes, Unanticipated Failures: Social Policy from Cardoso to Lula”, in P. Kingstone e T. Power (eds.), Democratic Brazil Revisited. Pittsburgh, University of Pittsburgh Press, pp. 161-184.

MAINWARING, Scott. (1993), "Democracia Presidencialista Multipartidária: O Caso do Brasil”. Lua Nova, no 23/24, pp. 21-74.

PEREIRA, Carlos and MUELLER, Bernardo. (2000), "Uma Teoria da Preponderância do Poder Executivo: O Sistema de Comissões no Legislativo Brasileiro". Revista Brasileira de Ciências Sociais, vol. 15 no 43, pp. 43-67.

PINTO, Julio Roberto S. (2009), Poder Legislativo Brasileiro: Institutos e Processos. Rio de Janeiro, Forense.

SANTOS, Fabiano. (2003), Poder Legislativo no Presidencialismo de Coalizão. Belo Horizonte/Rio de Janeiro, UFMG Editora/Iuperj.

SANTOS, Maria Helena C. (1997), "Governabilidade, Governança e Democracia: Criação da Capacidade Governativa e Relações Executivo-Legislativo no Brasil PósConstituinte". Dados, vol. 40, no 3, pp. 335- 376.

WILSON, James Q. (1973), Political Organizations. NewYork, Basic Books. 
